\title{
Clostridium difficile sýkingar. Vaxandi heilsufarsvandamál á Vesturlöndum
}

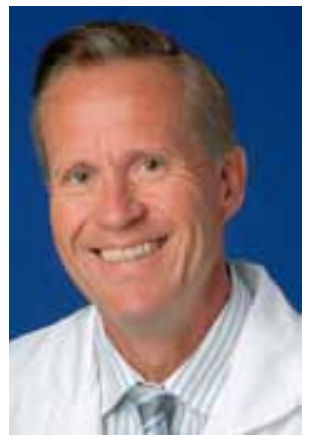

Einar $\mathbf{S}$. Björnsson

einarsb@landspitali.is

Höfundur er meltingarlæknir við Landspítala.

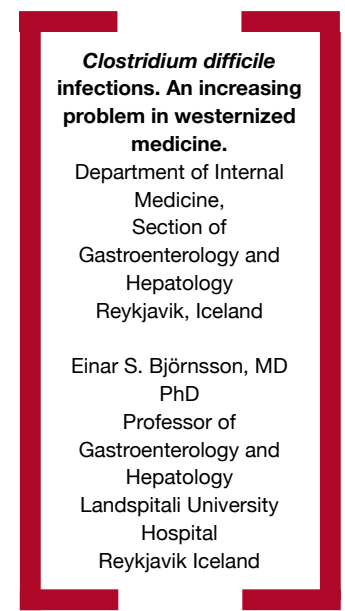

Clostridium difficile sýkingar (e. Clostridium difficile infections (CDI)) hafa verið pekkt heilsufarsvandamál í fleiri áratugi. Mikilvæg rannsóknarvinna hefur aukið pekkingu okkar á klínískum greiningaraðferðum, faraldsfræði og meðferð pessara iðrasýkinga. Tíðni CDI hefur farið vaxandi víðast hvar á Vesturlöndum og meinvirkari stofnar hafa komið fram. Faraldrar hafa einnig brotist út á mörgum stöðum í heiminum og fleiri alvarlegar sýkingar og aukin dánartíðni hafa fylgt í kjölfarið. Kostnaður heilbrigðiskerfisins hefur aukist að sama skapi sökum pessa. Afleiðingar CDI eru langvarandi spítalalegur vegna hvimleiðs niðurgangs, blóðsýkingar og lost í kjölfar hennar, ristilrof og brottnám ristils. Í byrjun pessa áratugar var lýst faröldrum í Quebec í Kanada af CDI par sem tilfellum fjölgaði gífurlega ásamt fjölgun alvarlegra afleiðinga pessara sýkinga. ${ }^{1}$ Faraldrar pessir einkenndust af fjórum til fimm sinnum hærra nýgengi af CDI og aukinni dánartíoni frá 4,5\% árið 1991 upp í 22\% árið 2004. ${ }^{1}$ Faröldrum af pessu tagi hefur einnig verið lýst í Evrópu. Fjöldi CDI tilfella í Bandaríkjunum virðist sífellt fara vaxandi og á síðustu árum hefur verið áætlað að um 450.000-750.000 tilfelli eigi sér stað par í landi á ári. ${ }^{2}$ Sterk tengsl á milli sýklalyfjanotkunar og CDI hefur verið pekkt áratugum saman en aukning af CDI tengd notkun prótónupumpuhemla hefur nýlega verið lýst. ${ }^{3-5}$

Rúnar Bragi Kvaran og félagar hafa gert parfa samantekt á faraldsfræði og alvarleika CDI á Landspítala á síðasta áratug sem birtist í pessu tölublaði Læknablaðsins. Í ljós kom að innsendum sýnum fjölgaði mjög á tímabilinu en ekki að sama skapi fjölda CDI jákvæðra tilfella. Pó svo að tilhneiging væri til pess að CDI tilfellum fjölgaði átti sér ekki stað augljós aukning á tímabili rannsóknarinnar. Grein pessi er að mínum dómi vel skrifuð og niðurstöður vel ígrundaðar. Pví miður hefur spurningunni um próun alvarlegra CDI tilfella síðustu ár ekki verið fullsvarað. Einungis 237/1492 (16\%) af sýkingunum á pessu 11 ára rannsóknartímabili voru rannsakaðar með tilliti til áhættupátta, birtingarforms, meðferðar og afdrifa sjúklinganna.
Samkvæmt niðurstöðum úr pessu úrtaki höfðu rúmlega $70 \%$ af sjúklingunum tekið sýklalyf innan priggja mánaða fyrir greiningu sýkingar sem hefur til pessa verið talinn aðaláhættupáttur peirra. Enginn sjúklingur í pessu úrtaki lést af völdum sýkingarinnar eða purfti að gangast undir aðgerð hennar vegna. Sökum pess sem áður segir að einungis tókst að kanna afdrif lítils hluta sjúklinganna er pví óljóst hvort CDI tilfelli hafi orðið alvarlegri á síðasta áratug. Hjá allra flestum sjúklinganna dugði að fá staka lyfjameðferð með metrónidazóli. Pó skorti upplýsingar um meðferð í sjúkraskrám hjá rúmlega $20 \%$ sjúklinganna.

Allir peir sem unnið hafa við aftursýnar rannsóknir sem byggja á að safna upplýsingum úr sjúkraskrám vita hversu mjög sú braut er pyrnum stráð. Pví miður vantar alltaf einhverjar mikilvægar upplýsingar og oft er erfitt að geta í eyðurnar. Pegar um er að ræða sjaldgæfa sjúkdóma eru framsýnar rannsóknir oft ekki mögulegar. Hins vegar er eins og gefur að skilja ákjósanlegt að gera framsýnar rannsóknir pegar pess er kostur. Samkvæmt rannsókn Rúnars Braga Kvaran og félaga er fjöldi pessara sýkinga af peirri stærðargráðu hér á landi að pær eru vel til pess fallnar að gera á peim klínískar framsýnar rannsóknir. Nýlega hófst framsýn rannsókn á CDI á vegum meltingardeildar Landspítala í samvinnu við Lyfjafræðideild HÍ með áherslu á nákvæma lyfjasögu sem aflað er af lyfjafræðingi ásamt pví að kanna árangur meðferðar og önnur afdrif sjúklinganna. Prótónupumpuhemlar verða kannaðir sérstaklega sem áhættupáttur.

1. Pépin J, Valiquette L, Alary ME, et al. Clostridium difficileassociated diarrhea in a region of Quebec from 1991-2003: a changing pattern of disease severity. CMAJ 2004; 171: 466-72.

2. Zilberberg MD, Shorr AF, Kollef MH. Increase in adult Clostridium Difficile-related hospitalizations and casefatality rate, United States, 2000-2005. Emerg Infect Dis 2008; 14: 929-31.

3. McFarland LV, Clarridge JE, Beneda HW, Raugi GJ. Fluoroquinolone use and risk factors for Clostridium difficile-associated disease within a Veterans Administration health care system. Clin Infect Dis 2007; 45: 1141-51.

4. Dial S, Delaney JA, Barkun AN, Suissa S. Use of gastric acid-suppressive agents and the risk of community-acquired Clostridium difficile-associated disease. JAMA. 2005; 294 : 2989-95.

5. Bishara J, Peled N, Pitlik S, Samra Z. Mortality of patients with antibiotic-associated diarrhoea: the impact of Clostridium difficile. J Hosp Infect 2008; 68: 308-14. 